\title{
17: 45633992-45616456
}

National Cancer Institute

\section{Source}

National Cancer Institute. 17:45633992-45616456. NCI Thesaurus. Code C41979.

Physical location of COL1A1_Gene 